\title{
Absolutizing the Particular
}

\author{
Robert J. Antonio
}

From the late-1960s to the mid-1980s, Telos brought the Frankfurt School, Western Marxism, and other critical Continental thought to North America and the English speaking world; it was the critical theory organ of that era and best ever English language journal on the topic. Its left lean did not compromise its critical view of communist regimes and left-wing parties and thinkers. Its contribution with regard to critical theories, with Hegelian-Marxist roots, was so substantial and widely acknowledged that many former readers and, I expect, even some journal editors, who have advertised in Telos, during the last 25 years, did not grasp its mid-1980s change of course. Although often portrayed narrowly, Telos' content, contributors, and editors have always been diverse.[2] Yet even in its early years, the Telos circle generally agreed that the welfare state and liberal-left political culture were exhausted. Elaborated in decisive moves by editor-in-chief, Paul Piccone, Telos' later thrust inhered in his early exhaustion thesis. He held that critical theory already was obsolete in the mid-1970s, when it dominated Telos' pages.[3] An outspoken critic of the New Left, Piccone still carried on its radical antiliberal current in his own unique, highly intellectual, philosophical way, which led eventually to his and Telos' right-turn.

\section{Paul Piccone's Telos}

Paul Piccone's smiling image on the cover of the "In Memoriam" issue of Telos' (nu. 131) brought back vivid memories of him from the1970s and 1980s. I met Paul when we both served as critics in a theory session at a St. Louis, sociological meeting in spring 1976. I had been a casual reader of Telos for several years, and I had assigned his translation of Enzo Paci's (1972) fusion of Husserl and Marx in the first graduate seminar that I taught. Several of my colleagues and many of our graduate students were engaging Marxism and other critical theories. [4] Although not a "Marxist," I was exploring Marxism and the cultural left. However, I found Althusser and friends dogmatic and impenetrable, and felt similarly about Lukács. I had an NEH Fellowship in 1974-75 to study Husserl, Hegel, and Kant and entertain alternative foundations for sociology. I was far less developed theoretically than Paul, but I thought our views converged and I looked forward to meeting him in St Louis. I spoke before Paul. When his turn came, he put aside his assigned target, and attacked me- "Open the door, close the door," he screamed, "you don't call bullshit, bullshit!" He blasted me for stooping to engage examples from an analytical philosopher and providing a "pusillanimous" critique. Then he delivered a blistering, deafening diatribe against the other theorist (his friend!). The audience was bemused, but entertained. Vintage Piccone it was. After the session, he invited me to stop by his Washington University office; that conversation was the first step toward forming the Kansas Telos Group. [5] Our paths diverged sharply later, but Paul and Telos had a formative impact on my thought, and its imprint remains. Importantly, Paul's candid style, dynamism, imagination, combativeness, and human qualities commanded the loyalty of his circle and shaped his journal's tone, direction, and contents. As Alain de Benoist (2005:49) declared: "Since its creation, Telos owed everything to him.'”[6]

Telos' operated within boundaries set by Piccone; he "owned" the journal, and led by intellectual combat.[7] Critics charged that Telos was devoted to rehash, but, with inevitable compromises, it published pieces that Piccone hoped would move the discourse in directions that he thought necessary. Embracing a much revised version of critical theory's historicism, with a phenomenological twist, he engaged critical theories old and new to transcend them. 
Paul pushed indefatigably for fresh engagements, asserted new directions vociferously, battled resolutely his circle's dissenters, urged them to come along, and, at key junctures, initiated confrontations, which led to bitter departures of editors and contributors. In these battles, he reasserted, often brilliantly, what was left behind and what needed to be engaged. He continually pressed his circle to reassess Telos' location and rethink and change it. Telos' 1980s, rightward drift, especially its turn to Carl Schmitt, severed its Hegelian-Marxist roots. The Telos circle redefined "critical theory" to mean "sustained critical reflection on the presuppositions of theoretical work" (Telos Staff 1990: 130). Never mincing words, Paul declared: “...Critical Theory was but another philosophically souped-up Marxism beset by all the traditional problems associated with the latter. The Hegelian formaldehyde shot into its stiffening veins only succeeded in neutralizing the putrid odor exhumed by surrounding decaying Stalinist carcasses" (Piccone 1990: 4). Yet he insisted that Telos stayed true to the telos of his scuttled Husserlianized, critical theory (i.e., "to reground the Western tradition—not as univocal or necessary, but as a contingent historical project...) (Piccone1988: 8). Even after embracing tradition and religion, he asserted that: "the original teleology thrives" in Telos. However, tensions inhered between his search for a "ground" and his post-Hegelian move. His phenomenologically informed "historicism" provided a methodological rationale for changes of political direction, but his long-held belief about the liberal-left's exhaustion was decisive in his reading of history and setting of Telos' course.

\section{| Piccone's Cultural Exhaustion Thesis: Artificial Negativity and its New Class Agents}

My first piece in Telos was a report on the May 1977, Antioch Telos Conference, where Piccone unveiled his "artificial negativity" thesis, presenting a paper, "Beyond Critical Theory," which foreshadowed the journal's future. [8] He contended that Marcuse's and Habermas' efforts to transcend Dialectic of Enlightenment critical theory were dead-ends, which could not possibly help escape the "one-dimensionality crisis." [9] Piccone held that critical theory addressed the transition from entrepreneurial capitalism to monopoly capitalism, but that the "full domination of capital" and consequent extreme homogenization, depersonalization, and routinization made bureaucratization "counterproductive" and ushered in the age of "artificial negativity." He argued that pseudo-reformist and pseudoradical organizations, policies, ideas, and movements (e.g., the welfare state, liberal-left egalitarianism, and civil rights, feminist, environmental, and consumer activism) are system generated simulations of reform and resistance, which intensify and even maximize the liquidation of particularity. Paul claimed that "organic negativity,"or spontaneously generated (from outside the system) opposition to homogenization, is a functional necessity of monopoly capitalist regulation required to avert dire legitimation and rationality crises. His functionalist move provided a quasifoundationalist deus ex machina that made “organicity" providential.[10] Piccone's idea of organic negativity was vague and abstract, lacking historical specificity, but his reference to "organic community" hinted where he and Telos were headed." [11] Piccone ([2001] 2005:163) explained later that he and his allies did not know how to elaborate organic negativity, when he framed his artificial negativity thesis, and that it "took us 20 years to be able to figure out what this was about." Roundly criticized by the Antioch conferees, his provocative thesis remained a contested terrain in the Telos circle for years.[12]

Piccone later specified that the cultural driver of artificial negativity and chief evaporator of cultural particularity is expansionary, universal human rights and egalitarian rights claims and consequent statist impositions that undermine local cultures and communities. His thesis made the progressive social and welfare arms of liberal democracies and their supportive civil society organizations, movements, and spokespersons, rather than capitalism, the main problems and enemies. As Paul refined these ideas, introduced fresh facets, and added allies to Telos, his exhaustion thesis became a boundary line between members of the circle, who shared emphatic antiliberal views, and others, especially the Habermasians, who were not ready to dump liberal democracy and were uncomfortable with Telos' rightward drift.[13] Piccone tirelessly reasserted his position against critics and eventually prevailed, radicalizing 'Telos' antiliberalism and relocating liberal democracy, the welfare state, the New Deal, human rights, and egalitarian, statist policies on the same continuum with fascism, Nazism, and communism. Editors, contributors, and readers, who openly rejected his view, left the fold, but others, remaining loyal to Piccone, did not necessarily embrace his exhaustion thesis in toto or its political directions.[14]

Paul presented his artificial negativity thesis to a much larger, more diverse audience at the student sponsored “Totally Administered Society" conference at Telos' Washington University home in February 1978. The numbers, intensity, and excitement of attendees made this meeting an early Telos' highpoint.[15] Piccone's thesis and the Telos 
circle's ideas about the exhausted left animated the sharpest debates. At the start, however, Piccone's colleague and ally, Alvin Gouldner defended liberal-democratic bureaucracy's progressive facets, stressing its qualitative difference from totalitarian regimes and the superiority of its rational-legal authority over tradition. He rejected the Telos' circle's idea of total administration, and undercut the bases and directions of the artificial negativity thesis.[16] Presenting in the same session, Telos editorial associate, Jean Cohen attacked Gouldner's yet unpublished "New Class" thesis (which he had not addressed in his talk). Piccone and key members of the Telos circle had been discussing the idea. [17] Like Habermas, Gouldner employed a linguistic turn to reconstruct critical theory. By contrast to Habermas, however, he specified a primary carrier stratum of the discursive resources; a New Class of technical intelligentsia and intellectuals who share a "culture of critical discourse," which along with their technical skills, make them ascendent over the old ruling bureaucratic and monied strata. Although the New Class is "badly flawed," he held, its cultural resources make it the "most progressive force" or "the best card that history has presently given us to play."[18] Gouldner had high hopes for liberal-left, academic intellectuals, whose critical capacities, he claimed, are more highly refined and who are neither as well paid nor are as well integrated into the system as technical professionals. His theory contradicted already well established neoconservative, New Class arguments, which portrayed liberal-left policymakers, officials, academics, and activists as a hegemonic, narrowly self-interested, predatory cultural and bureaucratic elite. They saw liberal-left intellectuals to be master ideologues and planners of the moribund New Deal policy regime and welfare state (e.g., Steinfels 1980: 188-213, passim). In the 1980s, Piccone inverted Gouldner's idea and converged with the neoconservative view, identifying liberal-left bureaucrats, activists, and intelligentsia, as hegemonic New Class architects and managers of cultural homogenization and liquidation of particularity. Piccone and the neoconservatives knew that Milovan Djilas' had earlier used the term New Class to portray communist bureaucrats and that it was politically opportune to deploy the concept against New Deal liberals and the left. Naming the New Class as the collective agent of artificial negativity moderated the functionalist, systems theory logic of Piccone's exhaustion thesis.[19] He likely would have taken up the New Class idea earlier, when he first formulated his thesis, but he did not want to align or be identified with the neoconservatives. During Telos' 1980s right-turn, this fear faded.[20] Piccone (1985:2) identified liberal-left "intellectuals as par excellence articulators of universalized particular interests [and] as new power brokers within a fraudulent new pseudo-egalitarian network." Yet he also charged that neoconservatives' and neoliberals' efforts to patch up crisis ridden, New Deal bureaucracy and blunt populist facets of the conservative movement indicated that they too belonged to the New Class (Piccone 198788). Neither theorizing the New Class sociologically nor providing historical analysis of its genesis, Piccone applied the term loosely to signify carriers, regardless of their social locations, of what he considered to be homogenizing, egalitarian ideology. He used the term politically, à la Schmitt, to mark boundaries between friends and enemies, but, given his southern Italian penchant for personal loyalty, he sometimes mixed the personal and political. After many defections, Paul employed New Class frequently, vehemently, and personally, especially, to attack Telos apostates or potential ones.[21] In derisive, name-calling, he charged that liberal-left academics were conformist "apparatchiks" and "cretinized," rent-sucking "nomenklatura." [22] By contrast to Paul, however, many Telos editors and contributors fed at the same academic trough, advancing to senior and sometimes to chaired positions at good and even elite institutions. Using New Class politically, the Telos circle did not reflect much on their own social locations.[23]

In the 1990s, Paul occasionally scribbled friendly notes asking what I was working on and encouraging my return to the fold. He hoped that I would explore John Dewey's relevance for Telos populism, but I could not imagine how Deweyan pragmatism could contribute to a project holding that liberal democracy and liberal-left individuality were exhausted and must be scuttled. Paul's last hand written note (September 22, 1998) said that I was "writing some pretty stupid things lately," that I was due for a "beating," and that I needed to defend myself or apologize for my bogus efforts. [24] I did not take up his offer. Our final engagement came about two years later. Following discussions of the New Right and post-liberal politics in Telos and on its listserv, I thought that Paul's vehement antiliberalism and antiegalitarianism and exceptionally hostile view of human rights and rights movements, whatever his intentions or personal inclinations, had affinity for reactionary populist, hard-right currents, which some Telos contributors and editors treated as benign forces and gave them tacit or open support. In year 2000, I posted comments on the Telos Forum about related matters, which drew heated responses from Paul. During a second round of exchanges, I was told that he was not well, and I withdrew from the forum.[25] Forwarded to me by a friend, a later posting by Piccone (2003) complained that Telos on-line participants' dissensus and poor grasp of issues precluded serious "collective dialogue" and that the Forum was near defunct. He also said that he hoped that: "Telos, or what remains of it, has not yet fallen into this funereal mood." He added, however, that the "original teleology thrives" in Telos (i.e., saving 
traditional Western values from capitalism and nihilism). He reaffirmed belief in this wellspring and world-historical mission until his passing (e.g., D’Amico and Piccone 2004:8).

\section{Modern Culture in Ruins: Telos' Radical Antiliberalism}

Rooted in the artificial negativity thesis, Piccone's idea that liberal-left democratic culture, institutions, and carrier strata are exhausted animated Telos's right turn.[26] Obliterating the qualitative differences between liberalism and fascism, Nazism, and Stalinism and pitting liberal democracy against organic community, he neutralized the liberalleft's antidemocratic ban and made way for friendly exploration of Schmitt, the Northern League, paleoconservatism, the French New Right, tradition, religious orthodoxy, and other topics, which, in early Telos, would have been attacked or dismissed. The shift finalized the break with critical theory, but brought to Telos new issues, ideas, and contributors, manifesting important political and intellectual trends. Piccone held that modernity's failed socialization processes and insipid commercial culture produce "abstract consumers," "narcissistic nihilism," and a surplus of drug-dependents and criminals. He saw the liberal-left's "paradigmatically 'bourgeois," vacuous, hypocritical, passive, abstract individual, "endowed with an ever growing list of human and civil rights," to be modern culture's nadir. He now considered modernity to be "a particular pathology of western culture" (emphasis in the original) (Delfini and Piccone 1998: 35, passim; Piccone 1998a:12-13, passim).

Paul Gottfried's (1994:172) succinct “After Liberalism," summed up pointedly Telos' trajectory at 100 issues; its "towering contribution" has been its attempt to expose " "liberal democracy" as flagrantly undemocratic." [27] Concluding this appropriately titled special issue ("Is There a Telos Left in Telos?), Piccone (1994: 206-08) scolded less stalwart editors for being "reluctant to stray beyond a reality limited exclusively to a present which, so impoverished, seems doomed to irreversible decline, betrays conceptual fatigue and helps explain some of their unintended conformism." In closing, however, his own faith in the arrival of his populist subject ("citizens qua autonomous individuals") wavered, and he conceded that the only public audience likely to find Telos' arguments at all interesting are the New Class! He seemed to be at the edge, gazing into the abyss. Was there any place to go but back into the open arms of the Church? He now saw its Latin liturgy as a strategic site to resist modernity's pervasive “cultural alienation” and “decadence." [28] Berman's (2008:4) point that particularity "is tradition, which in turn is inextricably tied to religion” signified the terminus of Piccone’s long trek. Berman's comment appeared in Telos' 40th Anniversary Issue, in which retrospection and reflection about Telos's path was limited to a few paragraphs in his introduction. After Piccone's Telos this was.[29]

From Telos' early days, Piccone and his circle, treated extreme one-dimensionality and cultural homogenization as givens. Rather than a topic of inquiry, their vision of the liberal-left wasteland has been a presupposition or departure point. Their ideas about profound cultural and political exhaustion became more expansive and forceful as liberal-left editors and contributors exited and more emphatically antiliberal thinkers joined the fold. Their attack on the liberal-left became a fundamental critique of Enlightenment and modernity. Piccone's related idea of the New Class as an all-powerful, decadent bureaucratic and cultural leadership also operated as a "first principle." Contributors and associates, who challenged these beliefs, were attacked as New Class operatives or mindless exponents of its retrograde ideology. Liberal-left challenges were not excluded, especially when Paul thought that criticism of their perspectives was needed to advance his and Telos' views. However, Telos' Schmittean right-turn discouraged left-leaning contributors from writing for the journal.[30] Gouldner's point, in his1978 frontal attack on the early version of the artificial negativity thesis, was that extremely impoverished visions of liberal democracy open the way for ideas and politics that might lead to much worse states of affairs. Piccone's view of welfare state bureaucracy as quasi-totalitarian, dismissal of the threat and even the concept of authoritarianism, and treatment of doubts about these views as prima facie evidence of New Class sympathies evaporated the discursive space to entertain and debate Gouldner's type of critique. However, could the hesitators in Piccone's circle, berated by him in the Telos at 100 issue, have had lingering doubts about dumping a liberal democratic regime that served most of them well in their academic careers and everyday lives? Could any of them have shared Rick Johnston's bemusement with Piccone's and Gottfried's equation of liberal rights with absolutism and totalitarianism and dismissal of the historicity of rights claims? I am still bewildered by Piccone's assertion, in his original artificial negativity essay, that the civil rights movement was the US “counterpart” to the Holocaust. Right on Rick: "What planet is this?”[31] 


\section{|Absolutizing Particularity: Piccone's Schmittean Populism vs Deweyan Democracy}

Egalitarian rights claims can be abused.[32] However, Piccone's reduction of human rights discourses, initiatives, and protections to New Class drivers of domination and homogenization ignores the fact that the they also manifest aspirations for justice from below, anchor forms of legality that give vulnerable people some protection, and provide an ethical vocabulary to protest domination, terror, and war. His equation of egalitarian movements and critiques with political correctness manifests the same myopic one-sidedness. [33] Piccone attributed universal normative claims an animistic homogenizing force, and absolutized his imagined organic communities' particularity and autonomy. He rejected universalism, but implied that populist local autonomy should be the rule everywhere. When pushed, he held that his view was based on his fallible decision, informed by concrete history.[34] His Schmittean move ignored, or tacitly accepted as necessary, the historical ways individuals, in the absence of the countervailing power of voluntary association and liberal rights and legality, have been harnessed to familial elites, clientelist hierarchs, churches, and other compulsory associations. [35] Granting total privilege to local culture, he argued that Lincoln "had no business" attempting to force the South to stay in the Union. In Piccone's view, the North still could have declared war to free the slaves, but he doubted that the American public would have supported such an action. Moreover, he reduced lynching of black people in the Jim Crow South to a "resentful over-reaction within defeated Southern communities, whose laws were imposed from the outside and were considered illegitimate.”[36] Was slavery's unspeakable violence and cruelty a better state of affairs? Piccone seemed untroubled about the fate of subordinate status groups in organic communities. He held that populist community has "nothing to do with race and ethnicity" and that it can accommodate substantial difference within its shared culture (e.g., Normans speaking Arabic dialects as well as French and attending Mosques) (Piccone 1999b: 156). Regardless of sweeping New Class homogenization, he held, organic communities survive in "the American heartland"(e.g., in Kansas), where belief in tradition and personal freedom are still the rule. Yet he warned that these islands of cultural particularity will soon be leveled "unless the modernist logic is reversed." [37] Eliminating this threat, however, requires dismantling the liberal-democratic cultural, institutional, and legal regime, in which these communities are now embedded. Piccone left vague the alternative form of local rule and possible consequences for minorities, and did not entertain and, in fact, dismissed the idea that populism, in the absence of liberal legality and countervailing power, might harden the racial, ethnic, and religious divisions and animosities that suffuse many actually-existing communities and populist movements (e.g. Zeskind 2009).

Piccone's (1982) memoriam to his father's passing provides context for his absolutizing of the particular. Paul explained that his parents moved from their native, small-town of Celano, Italy to the provincial seat of L'Aquila to make a living. Although just "on the other side of the mountain," the Aquilani spoke a different dialect and their city drew other regional migrants, who were also pushed there by economic necessity and shared other dialects and local cultures. Paul was born in L'Aquila, but he implied that his Celanese cultural traits made success at school and development of close friendships difficult and turned him inward to his family. He held that his nuclear family never acclimated fully to L'Aquila and that, from his: "earliest recollections, we never really felt at home anywhere, which meant we had to be at home everywhere_-but only as outsiders" (Piccone 1982: 2,10).[38] The family's immigration to the US posed fresh challenges. However, Paul vented about his brother adjusting too well to American ways and lacking proper Celanese respect for their father (i.e., failing to offer Papà a drink and eating dinner before he arrived for a visit). Piccone (1982:15-16) said that his brother forgot all that he was taught at home and that he personified upwardly-mobile, middle-America's "worst features"; "fashionable nihilism," "genteel superficiality," and "easy-going plastic mellowness of the Pepsi generation." He attributed his brother's pathologies to the: "cretinizing effects of exchange relations to which consumer culture reduces everything, including the primacy of blood relations.'Years later, Paul held that populist community, governed by shared values and norms, was the cure for this toxic deracination and nihilism. He believed that "postmodern populism's" traditionalist normative consensus would immunize people against today's rootless ennui and the xenophobic prejudices of earlier populist currents. Paul claimed that his populism was in tune with John Dewey's view of community and radical democracy. However, Dewey rejected Piccone's conventionalist type of social psychology, seeing it as a manifestation of Western philosophy's dualism and "quest for certainty," which precludes reflective selves and opens the way for prejudicial judgments.[39]

Following Jefferson, Dewey and Mead held that the "moral sense" is forged initially and is sustained in face-toface relationships. Piccone shared this view. However, Dewey and Mead did not argue that community is constituted by conformity to internalized norms or that value judgment and normatively-guided action can be equated with application of a norm per se.[40] They held that people reach understandings and cooperate by imagining themselves 
in the place of the other emotionally and instrumentally, meshing their action accordingly, and modifying it through reciprocal communicative acts. They did not anchor their idea of social integration in shared norms or collective identities alone, but in the capacity to compassionately take the attitude of the other. Norms can be applied rigidly, they argued, but they also serve as "principles," which orient and facilitate attitude sharing. In their view, primary emphasis on normative consensus and obedience easily justifies "good conscience" about divisive or repressive institutions, such as slavery, and undercut the wider attitude sharing needed to communicate and deliberate about problems, adapt to changes, and preserve or build community. Even when slavery is "normative," attitude sharing makes possible local opposition and resistence.[41] Dewey and Mead held that cultures can mix, coexist, and thrive, and nurture healthy selves; one does not have to embrace the life-style or values of the other to share attitudes and reach understandings. They argued that extensive, fluid networks of voluntary association, much of it indirect and distant, now contribute to creation of multiple, dynamic layers of selves and that this social matrix of modern individuality precludes the autonomous localism championed by Piccone. Dewey and Mead theorized that complex association individuates, and saw no path back to simpler orders, only poor or abject simulations thereof. They held that the type of autonomous, reflexive individuality is the only genuine or healthy alternative to the atomized, lost, or "bewildered" individuality of Middletown, Americana, still clinging to a mythologized past (Dewey [1929] 1988, pp. 46-49).

Dewey and Mead held that social modernity generates myriad conflicts and problems, but also makes possible wider capacities for sharing attitudes, and, thus, reaching understandings and cooperating with others different from oneself, powers which were less developed in simpler, self-enclosed, cellular orders of mostly compulsory association. Moreover, Dewey and Mead did not attribute transcendental status to universals, but treated them as social constructs, which help facilitate wider patterns of communication and association. They acknowledged that universals, treated as rules or enacted as laws, are sometimes reified or imposed arbitrarily, and, thus, lack substantive legitimacy. However, Dewey and Mead saw community and democracy to be flawed works in progress. They held that fragmentation derives not from social diversity or normative differences per se, but from gross failures to achieve substantive justice, substantive freedom, and other conditions that favor effective attitude sharing. Piccone considered Dewey's New Deal era, left-egalitarianism to be an aberration of his later thought, but, from the start, he argued that just provision of the means of cultivation and participation are essential for creation of well-formed individuals, communities, and democracies. Piccone's Schmittean-accented beliefs in cultural incommensurability, anti-egalitarianism, and friend-enemy dynamics, colored strongly by his own experience of deracination, animated his anti-Deweyan, populist conservatism.

Deweyan civic republicanism and Schmittean political theory are profoundly opposed theoretical visions. Piccone and his allies in the Telos circle put a halo around tradition and reduced modern individuality and its correspondent rights and legal protections to pathology. They implied that the individual, being prone to destructive excesses, benefits from the strong hand of the community's normative and political authority and that exercise of this authority is essential to community survival and preservation of global cultural pluralism. This view could easily morph into authoritarian statism, ostensibly grounded in local particularity, but actually corrosive to it. The neopopulist core of the Telos circle either has been uncritical or less candid than Schmitt about the primacy of power and political obedience within their hoped for regime. They left vague how organic communities, in a post-liberal world, would be governed and how power would be distributed, exercised, and limited.[42] How would real, corporal individuals fare in a regime that unburdens them of liberal rights and legality and grants such total privilege to the "community" and its leadership? What groups would likely embrace these views today, and for what purposes? What consequences would these antiliberal ideas have if they were taken up widely in existing polities and communities? Being troubled by such issues, Dewey valued liberal individuality and rights as much as community, and saw them to be entwined, necessary facets of democracy, which he hoped would be broadened in scope and better secured, rather than scuttled. By contrast to the Telos circle, Dewey saw modern individuality, however problematic and rife with contradictions, to be one of the US' most treasured cultural resources, and he called its egalitarian facets American culture's prophetic, "spiritual factor." [43] Deweyan theory and Schmittean theory offer divergent views and critiques of liberal democratic regimes. Departing from contradictory teloi, however, they are "enemy" positions, which call for contrary types of authority, power relations, and reconstructive paths. And they could constitute polar political options, in a future moment of decision, if the current crises deepen and the bullet hits the bone. 


\section{| Paul Piccone's Telos: A Contested Legacy}

Paul Piccone's Telos will be remembered for bringing Frankfurt School critical theory and certain other threads of Western Marxism to the English speaking world. The Telos circle's continued references to the "original teleology" and "Critical Theory" imply primacy of its early identity.[44] However, Telos' lasting contribution is an inherently contested terrain; others will surely give primacy to its Schmittean turn and the engagements that followed. Paul's vehement antiliberal trajectory brought diverse, new approaches to Telos, which had received scant attention in mainstream and liberal-left journals. His inexhaustible effort to elaborate and rethink his theoretical vision, in a changing historical landscape, animated Telos' battles, shifts, and richness. His acute sense for important, emergent trends in thought, ability to integrate key facets of them into his theoretical vision, and express new twists incisively and with much polemical flare made Piccone's Telos a very lively venue. He posed basic challenges to liberal democracy, liberal-left culture, and the modern self. One can disagree with his direction, but concur about the need to address the current regime's mounting crises (i.e., cultural, economic, environmental) and rethink it. Others have portrayed, better than I ever could, Paul's unforgettable qualities as a person, editor, and intellectual. I value especially his unwavering sense of vocation. He never rested. Paul said that Papà taught the kids to "work hard, persevere, have confidence in ourselves, and to follow the Celanese version of a Kantian categorical imperative." He also said: "Papà died the same way he lived: he did what he could, the best way he know how"(Piccone 1982: 16). So did Paul. And as Paul said of his "friend" and kindred spirit, Gouldner, with whom he disagreed fundamentally over theory, "tutto d'un pezzo" was he.[45]

\section{Endnotes}

1. My colleague David Smith provided incisive criticism and very helpful suggestions.

2. Editor-in-chief, Paul Piccone often lamented the Telos circle's lack of consensus. Summing up more than twenty-five years of Telos, Piccone (1994:173) declared: "After all these years, nothing seems to be settled and the editorial board remains a hopelessly heterogeneous group still trying to come to agreement concerning many crucial and not-so-crucial issues, such as precisely what constitutes this conservative involution, who has fallen victim to it, what the journal originally sought to accomplish, what it in fact accomplished, and what it should be doing now and in the future." However, he claimed that the internal theoretical warfare derived from the Telos circle's tendency to question everything and reject conformism. Even after the right-turn and Piccone's passing, the Telos' editorial associates had diverse views.

3. Piccone (1976: 179, passim; 1977) held that abandoning "critical theory's fundamental tenets," or its Hegelian-Marxist facets, was necessary to escape its "objectivist," or reified idea of collective subjectivity, which he argued subverts its emancipatory aims and has affinity for totalitarianism. Piccone continued to use the term critical theory, but broke with the established tradition. Many of his co-editors did not agree with him, and even he thought that Telos had to debate critical theory to supercede it. Thus, Telos published many critical theory pieces through the early 1980s and, thereafter, occasional pieces, on topics that fit the journal's agenda.
4. As a graduate student I had participated in antiwar activities and in a group supportive of the United Farm Workers. However, I never embraced New Left revolutionary rhetoric.

5. The Kansas Telos Group was always too loose an operation, in Piccone's view. It lasted formally for about four years (late 1976 to1981). After its dissolution, I occasionally reviewed manuscripts and wrote a few reviews and an article for the journal. My role was modest.

6. Benoist (2005:48-9) stated: "As a person, Piccone was loud. He would express himself in an English particular to only to him, with endless phrases evoking his native Italy. When he explained, argued, polemicized, it was always in an explosive manner. The words would cascade hurriedly out of his mouth. Not everything was understandable, but one could see his face light up with a large smile. He was volcanic, passionate. He also had a big heart." Piccone's long-time associate and former student, Tim Luke (2005:1) said that Paul was often "brusque" in initial meetings and that his voice defined him-“its sound engaged, enraged, or entranced, but his voice is what most will rememberfirst, and maybe last-about him." Piccone's writing was just as memorable. Spiked with sarcasm and whit, his rants were hilarious, especially when they were directed at someone else. His humorous repartee skewered, incited, dunned, scolded, and urged. His polemics in Telos' Editors' Newsletters and under his nom de plume, in the journal, were funny, lively, and usually incisive. I felt christened into the Telos family 
when Paul closed a letter (May 30, 1977) to me with: "You of course, remain as full of shit as always, but that's OK." A memorable late afternoon visit with Paul to the household of one of his family members living near Montreal, during an early 1980s, American Sociological Association Meeting, made demonstrably clear to me the cultural roots of his demeanor. His loud talk, animated gestures, intensity, work habits, and valuation of personal loyalty reminded me of my own larger than life, older relatives, all originating from small, hill towns east and southeast of Naples

7. Paul was a creative, energetic, forceful editor. He set directions emphatically in Editors' Newsletters, letters to contributors, rejection letters, face-to-face interactions (especially at Telos events), and Telos introductions, reviews, and essays. See e.g., Jay (1977) and Arato and Piccone (1977) for debate over Telos' friend-enemy boundaries with New Left Review.

8. Traces of the thesis appear in Piccone's earlier work. Piccone (1978a) published his Antioch essay, under a different title in Telos, followed by Tim Luke's (1978) companion piece. For my report on the Antioch conference, see Kansas Telos Group 1977. See John DeBrizzi's (1978) charge that the artificial negativity thesis drifted "beyond" any type of Marxism or critical theory, and Luke's and Piccone's (1978) response that they had historicized Marxism. Piccone (1994:185, passim) later claimed that the artificial negativity thesis was consistent with his earlier phenomenological Marxism, but that his new view opposed almost everything in the left-leaning tradition and jettisoned all the Marxist philosophical and economic baggage.

9. These theorists framed alternatives to critical theory's historicist method of immanent critique, which supposedly had been subverted by the culture industry and mass consumption. On Marcuse and Habermas, see e.g., Piccone 1980; for a critique of Adorno, see Piccone 1983.

10. Piccone's functionalist move was an attempt to rescue immanent critique by providing a pseudo-sociological guarantee for social conditions that open the way for a yet to be named emancipatory subject. Piccone (1994: 193) later implied that this maneuver distinguished his artificial negativity thesis from Frankfurt School, culture industry pessimism. The substantive strategies diverged, but Piccone converged with Habermas's quasifoundationalist and Marcuse's aesthetic moves, which warrant that genuine negativity, or, at least, the potential resources for it, lurk below monopoly capitalism's surface, even when their cultural and political bases appear to be neutralized. Such moves manifest, what John Dewey called "the quest for certainty."

11. Mentioning 19th century American "populism" as antecedent organic negativity, Tim Luke's (1978: 6566) companion piece, appearing with Piccone's artificial negativity essay, provided a more direct expression of Telos' future direction. The Telos circle's early and mid1980s engagement of Christopher Lash's populist views helped them find their way home.

12. Paul nudged as well as fulminated to urge agreement with his views. In a letter (July 29, 1978) about a paper that I submitted to Telos (on Weber's theory of rationalization), Paul said that our ideas on bureaucratic planning converged, but that my analysis stopped fifty years early; the problem could be remedied, he said, if I employed what he "tried to articulate under the unfortunate label of 'artificial negativity." He added: "That's OK -- some of my best friends are also out of touch." See Kansas Telos Group 1977:190-91; See Fekete 1981-82:165-67.

13. The mid- and late-1980s Telos' Editors' Newsletters, which included exchanges between Piccone and departing editors, are informative about the break with critical theory and the editor-in-chief's lead role in the process. His departure exchanges with Mark Poster, Seyla Benhabib, Joel Kovel, and Jürgen Habermas are classics, but appended to the end (p.8) of the October 1987 newsletter, announcing the Schmitt special issue, Andrew Arato's, Jean Cohen's, Jose Casanova's, and Joel Whitebook's succinct resignation letter punctuated Telos' ongoing sea change, which started about six years before. In the later 1980s, Piccone entertained doing a special issue on "Critical Theory Today," but the discussion and slim results evidence the severed roots. A telling point, Piccone (1989b:19, passim) said that many of his editors did not have background in the tradition. See Piccone 1985; 1986; 1987; 1990; Telos Staff 1989-90.

14. In the December 1985, Editor's Newsletter, Piccone (pp.1-3) held that, after jettisoning the HegelianMarxist baggage, the Telos circle lacked a "fundamental internal consensus." However, he was sure about the needed direction to complete the paradigm shift. $\mathrm{He}$ reasserted his disregard for Habermasian theory ("biggest joke since the Playboy Philosophy..."), warned that a step back toward liberalism was a "step towards totalitarianism," and declared democratic ideology to be "exclusionary." These themes inhered in his decade old artificial negativity thesis.

15. Examine Spring 1978, Telos (nu. 35). Read the meeting report (St. Louis Telos Group 1978). Also, note the contributors, long lists of editors and group members, and persons who were already or later became leading social theorists and top thirdgeneration, critical theorists.

16. Barry Commoner, Oskar Negt, and others also criticized the Telos' circle's claims about the moribund left and the Picconean exhaustion thesis. After Paul's talk and the conclusion of formal presentations, during a summary panel discussion that included audience questions and responses, Gouldner (from the audience) attacked the Telos' circle's overall view of exhaustion and the artificial negativity thesis. Responding to a comment by Arato and provoked by an unfriendly audience, Gouldner's eruptive display, in a packed lecture hall, manifested, in part, tensions 
between the liberal-left and Telos' nascent political vision. The warm reception given to the avuncular elder, Murray Bookchin, libertarian-anarchist ecologist and sharp, antistatist critic of Marxism, suggest that the tensions were not merely generational.

17. Gouldner had led a summer 1977, NEH seminar on his New Class thesis at Washington University; Telos contributors Andrew Arato and Cornelis Disco attended (Gouldner 1982: “acknowledgments"[next to p. 1]). Piccone (1994:181) said that, when he was formulating his artificial negativity thesis, Telos was next door to the office of Gouldner, who was developing his New Class theory. Although disagreeing sharply on the New Class and the extent of political and cultural exhaustion, Piccone and Gouldner were kindred spirits. Gouldner was an acerbic critic, vehement enemy of the New Left, and self-acclaimed "outlaw Marxist." He had been banished from Washington University's, Sociology Department and physically moved to another building, for being a polarizing figure. Piccone (1981) wrote a Gouldner obituary in Theory and Society (which Gouldner founded and tirelessly led ). See also Charles Lemert and Paul Piccone 1982.

18. Inhering in the New Class' post-traditional roles and practices, Gouldner argued, the culture of critical discourse can be deployed to question, challenge, or change the system, but it also serves careerist interests and domination (e.g., power, money, status hierarchies). He held that its impact is historically contingent, depending on agency and circumstance. See Gouldner 1982: 7, 83-92; passim; see Antonio 2005 for an overview of Gouldner's critical theory.

19. The idea of New Class was already implied in the artificial negativity thesis. Naming the agent moderated, but did not eliminate the thesis' functionalist thrust, because Piccone still held that organic negativity is necessary to balance the system and avert legitimation crises. In 1981, Paul asked me to integrate the New Class idea into my Telos review of G. L. Ulmen's Wittfogel book. I do not recall if he suggested a concrete way to approach the New Class issue, but he definitely had the topic in mind at the time. He did not object to or alter my discussion of the neoconservative version of the idea in my review (Antonio 1981-82: 207)

20. Piccone's later populist "conservative"stance still rejected neoconservatism for its liberal globalist positions on capitalism, democracy, and human rights. He embraced the French New Right, but did not want to be identified with the right per se. Although declaring the right-left continuum moribund, he employed the terms right and left opportunistically in his polemics.

21. For example, Piccone (1994; 201-06) charged Telos, editorial associate and contributor David Ost with New Class sympathies for being too critical of capitalism, the market, populism, and the American right. In assessing Telos' direction at 100 issues, Ost had (1994) advised exercising more balance and collective self-criticism about its rightward populist drift. On the New Class, see e.g., Piccone 1989a:8; 1990-91; Piccone and Ulmen 1991; Telos Staff 1991.

22. The spleen Paul vented toward academics bore the imprint of his own bitter, arbitrary, unjust tenure decision. He thought that rational legality would prevail and that the Washington University Administration's move to deny him tenure would fail. Closing a letter to me on other matters, Piccone (July 29, 1978) said that he was optimistic about his tenure fight, because "political mistakes,"which led one dean to resign, would sink another if the negative decision was upheld. However, the new dean and administration turned him down. His liberal-left, Sociology Department, senior colleagues voted unanimously in his favor. Daniel Bell, Herbert Marcuse, Jürgen Habermas, Norman Birnbaum, Franco Ferrarotti, and other postwar era, social theory luminaries wrote external letters, recommending Paul's promotion and tenure. Piccone's (1978b; 1979) comments on the case and related documents appear in Telos Editors' Newsletters.

23. Regardless of the Telos circle's vitriolic attacks on "New Class" academics and claims about their journal's non- or anti-academic thrust (e.g., Piccone [2001] 2005: 158), it has been respected in key, albeit changing, academic circles and association with it has served as cultural capital for editors and contributors. The academic affiliations and lustrous named professorships of allies, contributors, and editors are displayed, with their bearers names, on the Telos web-site. Current editor-in-chief and longtime editorial associate and contributor, Russell A. Berman, holds a chair at Stanford and is Senior Fellow at the conservative Hoover Institution. Hardly on the margins is he. See the lengthy list of Telos scholars and academics that Tim Luke (2005), long-time Telos associate and chaired professor, appended to his remembrance of Paul. Telos' scholarly format has always been academic, although non-mainstream, even in political essays. Telos long-time bête noir, New Left Review shifted to a non-academic format and journalistic political style in its "second series,"starting with its January/February 2000 issue.

24. Paul wrote a similar note to Doug Kellner (copied to me) on the same date, hoping to recruit us for a Telos "late critical theory" issue and, of course, to correct us publically.

25. In early June 2000, a posting on the Telos Forum expressed shock that supporters of far-right Austrian politician, Joerg Haider, who occasionally spoke well of Nazism, had solicited on the Telos listserv. On June 5, another posting defended the solicitation, saying that Telos' opening to Haider and his fellow travelers was a sign of the journal's maturity. In response, I suggested that readers open a dialogue about affinities between the harder right and the paleoconservative and New Right essays that Telos published and scrutinize views that the contributors advocated on their websites and in their other writings. These postings stirred intense exchanges. Erupting, Paul charged me, in 
several postings, with a "spineless exercise in guilt by association," "covert dogmatism," "ontological economism," "crude Marxism," “"politically correct' conformism," "pusillanimity," and the type "academic crime" that Telos prosecuted. He defended Telos' rightturn, but not Haider. However, Piccone (2000a) said that Haider was no worse than "any other mediocre European politician, from Blair to Chirac..." Piccone (2000b) posted his "éléments Interview" to correct readers, like myself, who, he said, had "no clue" of what Telos was about and held "opportunistic, conformist, and otherwise silly politically correct positions." The comprehensive interview sheds considerable light on Paul's later thought and Telos' path and location (Piccone 1999b). In late October 2000, Paul and I had another exchange, on the Telos Forum, over a posting questioning the fate of a Jewish minority group in a gentile populist regime. I posted critical remarks about Paul's comments and about the interview that he had posted in June. Paul's response was scathingly dismissive.

26. See Piccone 1989b:22-23; 1999b: 140-44, for his claims about how his artificial negativity thesis deconstructed the left-right dichotomy and about its foresight and continued veracity. For later retrospection on artificial negativity and the New Class, see Piccone 2002.

27. See Piccone 1994: 206-08. Piccone stressed the importance of his artificial negativity thesis and New Class idea in setting the course. This retrospective issue (nu. 101) followed watershed special issues on The French New Right (nu. 98-99) and Federalism (nu. 100), which consolidated the sharper right-turn, started in the Schmitt issues (nu.71 \& 72) seven years before.

28. Piccone (1998a:14-16) held that liturgy's mediation of the immanent and transcendent is the ultimate basis of community, infusing people with hope and meaning and cultivating autonomous selves. He left the meaning of this autonomy vague. Anglican Catherine Pickstock's writings on radical orthodoxy helped provide a vocabulary for Piccone's religious turn.

29. Piccone shared Berman's (1999:48, passim) view that "religion becomes the Critical Theory of the fully enlightened world of dogmatic secularization."

30. Additionally, liberal-left authors knew that they would not have the last word and that they would be grist for Paul's mill. Paul's mention of a "beating" for me meant his last word. However, long after the Telos right-turn, its editorial associates still do not march in a theoretical lockstep. For example, Tim Luke, who continues to fashion his own distinctive, environmentally conscious version of critical theory, still serves on the editorial board with neoconservative Russell L. Berman, paleoconservative Paul Gottfried, and others who have rejected or have little or no connection to the journal's original, critical theory thrust.

31. "Both aimed at eliminating specificity and othernessone through extermination camps and the other through social integration...." said Piccone (1978a: 48-49). See the exchange between Gottfried 1999; Piccone 1999a; and Rick Johnston 1999: 139, passim, over Johnston's earlier mild-mannered reference about the need to protect liberal rights in populist regimes.

32. I concur with some points made by Piccone and friends on this topic; e.g., critiques of the employment of the US military to "spread democracy" and of academic identity politics.

33. My colleague, David Smith sees: "Piccone as symptomatic of the devolution of the New Left, of which he was very much a representative figure, however violently he may have resisted the idea. What started as active advocacy of civil rights, human rights, and participatory democracy devolved into the abstract negation of liberalism and humanism. The many different representatives of this devolution varied idiosyncratically in the flavor and focus of their illiberalism -- e.g., Maoism, Althusserianism, Marcusean apocalypticism -- but all scoffed at humanitarian ethics, egalitarianism, and reform."

34. Responding to my Telos Forum posting, Piccone (2000c) said: “... you accuse me of 'absolutizing the particular.'What does that mean? Unlike Enlightenment ideologues, Leftist dogmatists and religious fanatics... I still believe in the primacy of subjectivity, the necessity of making personal choices independently of whatever the higher forces in the universe supposedly warrant, etc. This means that action cannot be predicated on the contingent and relative, but must take whatever is deemed to constitute the historically concrete as absolutely given. There is always a chance of making mistakes and misjudging, but as they say in Kansas: it is better to have loved and lost than not have loved at all (or something to that effect)." Touché my friend!

35. As Michael Walzer (1997: 18, passim) explained: "members had no rights of conscience or of association against their own community." The Ottoman "millet system" was the classic example of how premodern empires kept the peace and preserved cultural particularity by harnessing individuals to selfgoverning religious and ethnic communities and their elites. There are many varieties of this local absolutism, and subjection of the individual.

36. Piccone (1991-92:3) held that the Civil War undermined original US federalism: "by hypostatizing axiological considerations above and beyond the law, leading to what Schmitt called 'the tyranny of value"'(by contrast, critical theory's emancipatory hopes rested on pitting value claims against "unjust" laws and structures). See Fleming 1995, for more on this line of argument. Gonzales 1998: 154; Berman, Piccone, and Ulmen1996:19-20, passim. See longterm, associate editor, Robert D'Amico's (1998) sharp critique of Berman, Piccone, and Ulmen(1996) and Piccone's (a.k.a. Gonzales 1998) unusually measured, but telling response. 
37. Delfini and Piccone 1998: 41, passim. Piccone did not know the American heartland. Variably across this region, fragments of traditional culture remain, but heartland people watch cable TV, navigate Internet, shop Wal-Mart, and depend on medicare, social security, and other welfare state benefits. Immigrants and other outsiders also reside in rural, small-town Kansas, but even among natives, who share some characteristic ways, local cultures have hybrid features and are seldom as resistant to the broader culture as Piccone claimed. Piccone charged that Arthur J. Vidich's and Joseph Bensman's ([1958] 1971) classic 1950s study of small town America exaggerated the homogenizing processes of modernization and suburbanization. A sometime resident of the town that they studied, Paul held that the community still retained its organic features nearly five decades after the postwar leveling forces were unleashed (Piccone 1995: 54-55). He argued that "New Class sociologists," like the coauthors, overlook the resistant cultural attributes of genuine communities. A long-time acquaintance of Paul, Vidich (2009 [in-press]) expressed bemusement about the charges that he posed in Telos. Vidich argued that Paul mistook the town's external appearance for organicity. Scathingly dismissive of sociology, Piccone seldom stooped to defend his sociological claims with "sociological" evidence. His claims about the heartland's organic cultural islands manifested his own apodictic judgements.

38. Ulmen (2005: 8-9) suggested a different view of L'Aquila's meaning to Paul, but also implied that his Abruzzese youth had formative impact of on his later view of community.

39. Piccone does not provide a detailed discussion of normatively oriented action and social pyschology, but he implies a conventionalist normative consensus; i.e., his "autonomous citizenry" would simply obey communal norms. He held that "the organicity of the communities constituting the most fundamental political units is a function of adherence to and internalization of collectively shared rules and regulations concerning social behavior, conflict resolution, general expectations etc." (Piccone 1995:53; see 56-74 on Dewey; 1994:198; 1992-93). Piccone's (1998b) lengthy review of Eh Paesan! provides insight into his later ideas about homogenized, southern Italian roots, multiculturalism, and the Catholic Church.

40. I refer to George H. Mead along with Dewey, because they collaborated on the issues discussed here. Dewey and Mead held that much of our behavior is habitual. However, they saw cooperative life to be fraught with problematic, ill-defined situations where habit fails. In these situations, actors have to decide which values and norms apply and provide the right guidelines and ethical vocabulary for the conditions at hand. Effective normative decisions, in these cases, require reflexive judgment geared to the specific conditions of particular situations.

41. Dewey and Mead held that people can employ multiple normative frames and types of attitude sharing in each situation; slaves may be engaged through varying lenses and emotional orientations. Even in slave societies, ethically reflexive people can recognize a slave's humanity and judge slavery unjust. Dewey and Mead saw attitude sharing to be a basic human capacity, enhanced or truncated, by varying social, psychological, and biological conditions. In their view, shared needs and common all-too-human, life situations, originating in early child-parent relations, generate capacities for cross-cultural communication and understanding. They also held that universals provide a vocabulary for wider attitude sharing, which arises via association and exposure to other cultures. Accordingly, they would have held that human rights are rooted in these capacities. Piccone (1982: 15) said that his brother's treatment of his father would have been unacceptable in other parts of the world. That one does not have to be Celanese to know how parents should be hosted is consistent with Mead's and Dewey's point of view.

42. Piccone sometimes held that his populist communities would be "direct democracies," but he said little about how they would operate or how they would arrange their power and authority relations. See Schmitt [1932] 1996: 40-48, 58-61, 68-73; Piccone 1996.

43. Dewey [1929] 1988: 48-49, passim; see e.g., Dewey [1939] 1988: 173-88, on justice and community in the US tradition. Piccone and Dewey converge in their critiques of capitalist or "pecuniary" individuality. However, Dewey embraced critically, modern American, secularized, Protestant-rooted individuality, stressing freedom of conscience and cultural pluralism within as well as between communities (compare Schmitt [1932] 1996: 40-45). Also, Dewey stressed the need to refine methods to better secure traditions, deemed worthy in everyday practices and democratic deliberations, but rejected emphatically adoration of tradition per se.

44. However, these terms have become floating signifiers long after Telos' sharp change of course. For example, Berman's (2008: 4; 1999) views about recognizing the emancipatory telos' demand for "a muscular response to danger" and framing a religiously-anchored critical theory have little to do with early Telos' telos and might be better portrayed in a different vocabulary.

45. "All of one piece" this means. Piccone (1981:167) praised Gouldner's "personal loyalty," willingness to fight, whatever the odds, and his "uncompromising," "tough," sureness of self, "unique contributions," and "extremely fertile lifetime." All characterized Paul. 


\section{References}

Antonio, Robert J. 1981-82. Review of "G.L. Ulmen.The Science of Society: Toward an Understanding of the Life and Work of Karl August Wittfogel.”Telos 50:197-210.

2005. "For Social Theory: Alvin Gouldner's Last Project and Beyond." Pp. 71-129 in Jennifer Lehmann (ed.), Current Perspectives in Social Theory: Questioning Social Change (Vol. 23). Amsterdam: Elsevier.

Arato, Andrew and Paul Piccone. 1977. "Rethinking Western Marxism: Reply to Martin Jay.” Telos 32: 167-74.

Benoist, de Alain. 2005. "Our American Friend Paul Piccone was a Free Spirit and a Loud Talker.” Telos 131: 46-49.

Berman, Russell A. 1999. "From Brecht to Schleiermacher: Religion and Critical Theory” Telos 115: 36-48.

.2008. "Introduction" Telos 143: 3-6.

Berman, Russell A., Paul Piccone, and Gary Ulmen. 1996. "Introduction: Racism, Multiculturalism, and Globalization" Telos 108: 3-24.

D’Amico, Robert. 1998. "Reply to the Introduction to Telos 108." Telos 110: 141-47.

D’Amico, Robert and Paul Piccone. 2004. “The Long March out of the 20th Century." Telos 127: 2-10.

DeBrizzi, John.1978. “Piccone's Fourth Dimension.” Telos 37: 144-47.

Delfini, Alex and Paul Piccone. 1998. "Modernity, Libertarianism and Critical Theory: Reply to Pellicani." Telos 112: 23-46.

Dewey John. [1929] 1988. Individualism, Old and New. Pp.41-123 in Vol. 5, 1929-1930 of John Dewey: The Later Works 1925-1953, edited by Jo Ann Boydston. Carbondale and Edwardsville, IL.: Southern Illinois University Press.

[1939] 1988. Freedom and Culture. Pp.63-188 in Vol. 13, 1938-1939 of John Dewey: The Later Works 1925-1953, edited by Jo Ann Boydston. Carbondale and Edwardsville, IL: Southern Illinois University Press.

Fekete, John.1981-82. “Telos at 50.” Telos 50: 161-71.

Fleming, Thomas. 1995. "Three Faces of Democracy: Cleisthenes, Jefferson, and Robespierre.” Telos 104: 51-67.

Gonzales, Moishe. 1998. “Liberalism vs. Populism.” Telos 110: $148-54$.

Gottfried, Paul. 1994. “After Liberalism.” Telos 101: 169-72.

. 1999. "Enforcing 'Human Rights': Rejoinder to Rick Johnston.” Telos 116: 135-37.

Gouldner, Alvin W. 1982. The Future of Intellectuals and the Rise of the New Class: NewYork: Oxford University Press.
Jay, Martin. 1977. "Further Considerations on Anderson's Considerations on Western Marxism.” Telos 32: 162-67.

Johnston, Rick. 1999. "Liberalism, Absolutism, and Human Rights: Reply to Paul Gottfried.” Telos 116: 139-42.

Kansas Telos Group. 1977. "The Antioch Telos Conference." Telos 32: 188-92.

Lemert, Charles and Paul Piccone. 1982. "Gouldner's Theoretical Method and Reflexive Sociology." Theory and Society. 11(6): 733-57.

Luke, Tim.1978. "Culture and Politics in the Age of Artificial Negativity." Telos 35: 55-72.

2005. "The Trek with Telos: A Remembrance of Paul Piccone." (January 19, 1940-July 12, 2004) Fast Capitalism 1(2) (http://www.fastcapitalism.com).

Luke, Tim and Paul Piccone.1978. "DeBrizzi’s Undimensionality." Telos 37: 148-52.

Ost, David. 1994. "Search for Balance." Telos 101: 137-54.

Paci, Enzo. 1972. The Function of the Sciences and the Meaning of Man, trans. Paul Piccone and James E. Hanson. Evanston: Northwestern University Press.

Piccone, Paul. 1976. "Paradoxes of Reflexive Sociology" New German Critique 8: 171-79.

. 1977. "The Changing Function of Critical Theory." New German Critique 12: 29-37.

. 1978a. "The Crisis of One-Dimensionality." Telos 35: 43-54.

1978b. “Telos Newsletter” Nu. 4 (May 11).19 pp.

1979. “Telos Newsletter” Nu. 8 (February 23). 31pp.

1980. "The Future of Critical Theory." Current Perspectives in Social Theory. 1: 21-30.

. 1981. "Alvin W. Gouldner. 1920-1980." Theory and Society. 10(2): 165-67.

1982. "Omero Piccone” (1914-1982) (April 20).16 pp.

1983. Review of "Theodore W. Adorno, Against Epistemology: A Metacritique.” Telos 56: 229-35.

1985. "Editors' Newsletter" (December 10) 21 pp.

1986. “Editors' Newsletter" (May 9) 28 pp.

74: 3-29. 
1987. "The Telos Public Sphere: Editors' Newsletter" (October 19) 8 pp.

1988. "20 Years of Telos." Telos 75: 3-25.

1989a. “The Telos Public Sphere: Editors' Newsletter” (January 26) $12 \mathrm{pp}$.

.1989b. "The Telos Public Sphere: Editors' Newsletter" (July) 26 pp.

1990. "The Telos Public Sphere: Editors' Newsletter" (October) $10 \mathrm{pp}$.

1990-91. "Artificial Negativity as a Bureaucratic Tool." Telos 86: 127-40.

. 1991-92. "Federal Populism in Italy." Telos 90: 3-18.

. 1992-93. "The Actuality of Traditions." Telos 94: 89-102.

1994. "From the New Left to the New Populism." Telos 101: 173-208.

. 1995. "Postmodern Populism." Telos 103: 45-86.

1996. "Ostracizing Carl Schmitt: Letter to The New York Review of Books." Telos 109: 87-91.

. 1998a. "Modernity, Liturgy and Reification: Remarks on the Liturgical Critique of Modernity." Telos 113: 11-18.

. 1998b. "Multicultural Homogenization." Telos 113: 173-200.

1999a. "'Human Rights" as 'Historical Universals." Telos 116: 143-46.

1999b. “éléments Interview." Telos 117:133-66.

2000a. "From_telos-forum: My two cents worth." Telos Forum (June 5 [18:48:54 - EDT). (telos-forum@icsun.ithaca. $\mathrm{edu})$.

.2000b. "From_telos-forum: Dear Forumers." Telos Forum (June 7 [11:45 AM - EDT]). (telos-forum@icsun.ithaca.edu).

2000c. "From Telospress.com: Dear Bob (Antonio, not D’Amico).” Telos Forum (June 7 [13:02:07 EDT]). (telos-forum@icsun.ithaca.edu).

. 2002. "From the New Left to Postmodern Populism: An Interview with Paul Piccone" [by Jorge Raventos]. Telos 122:133-52.

2003. "Approaching 60: Shock, Awe and Realignment" Telos Forum (July 17 [15:28:56 - 0400 EDT). (telos-forum@ icsun.ithaca.edu).

[2001] 2005. "Telos in Canada: Interview with Paul Piccone" [by Gary Genosko]. Telos 131:152-66.

Piccone, Paul and Gary Ulmen.1991. "Democracy and Federalism: Reply to Fraser.” Telos 88: 111-19.
St. Louis Telos Group. 1978. "The Totally Administered Society." Telos 35:169-84.

Schmitt, Carl. [1932] 1996. The Concept of the Political, trans. by George Schwab. Chicago and London: The University of Chicago Press.

Steinfels, Peter. 1980. The Neoconservatives: The Men Who Are Changing America's Politics. New York: Touchstone.

Telos Staff. 1989-90. "Does Critical Theory Have a Future? The Elizabethtown Telos Conference." Telos (February 23-25, 1990) 82: 111-130.

. 1991. "Populism vs. the New Class: The Second Elizabethtown Telos Conference (April 5-7, 1991)." Telos 88: 2-36.

Vidich Arthur J. and Joseph Bensman. (1958) 1968. Small in Town Mass Society: Class, Power, and Religion in a Rural Community (Revised Edition). Princeton NJ: Princeton University Press.

Ulmen, Gary. 2005. "Paul Piccone and Telos." Telos 131:4-12.

Vidich, Arthur J. 2009 (in-press). With a Critical Eye. Knoxville, TN: Newfound Press.

Walzer, Michael. 1997. On Toleration. New Haven and London: Yale University Press.

Zeskind, Leonard.2009. Blood and Politics; The History of the White Nationalist Movement from the Margins to the Mainstream. New York: Farrar Straus Giroux. 
